House of Commons.) A peculiarly British anxiety is that the government, having hived off much public administration to unelected committees, is now accused of filling them with people whose political friendship is more stringently tested than their competence.

But the common and offensive thread in this behaviour pattern is that people who are elected for a specific purpose, to represent their electors' interests, and who are paid a salary in recompense, end up representing some interests more vigorously than others, or arranging that some public duty should be discharged less than competently. These are simple breaches of the implied contract people running for election offer voters when seeking office. It does not matter that representatives are free to vote on specific issues according to their best judgement and their consciences. To be required to make an honest and unbiased judgement can also be a public responsibility. In that sense, the accusations against politicians are no different from an employee's breach of fiduciary responsibility to an employer. Britain exaggerates its own difficulties by allowing Members of Parliament to moonlight, often for parliamentary lobbyists.

How do those transgressions compare with growing indifference to conflicts of interest arising in research? To the extent that politicians' misdemeanours are a betrayal of public trust, they are in a class of their own. But the easy acceptance of conflict in research can also mean betrayal. This journal's puritanical view that academic researchers should never be officers of a separate commercial company, even one they set up themselves, has logic on its side; they would have to neglect their regular duties if the company were in trouble. But what of those who become stockholders in return for membership of an advisory board, or who favour one of several suitor companies with a consultancy contract?

The common practice, at least in universities, is that the institution will agree provided that regular duties are not neglected, which is usually enforced by limiting the time spent on outside work. But what if a person earns a substantial fraction of his or her annual salary in ways like that? Or if the stock appreciates remarkably? Such developments can readily undermine the trust on which members of productive laboratories mutually rely for their success. Will colleagues be free with their half-baked bright ideas if they do not know which company will hear of them next? In the research enterprise, there can be no alternative to the full disclosure of outside commitments, not only to institutional authorities but also to working colleagues.

But would not all academics then migrate to industry? That reflects many British politicians' defence of moonlighting in the House of Commons; salaries are so poor that members have to supplement their incomes. The simple solution is that they should be paid adequately, and that legitimate extra earnings (from speaking engagements and the like) should then be strictly limited, as they are in the United States. Why not follow the same recipe in research? A cap on consultancy and other earnings would be only seemly. Decent pay is long overdue if the research profession is not always to be overshadowed by those with longer pockets.

\section{Another rope trick}

The University of Chandigarh in India has been disgracefully lenient with Professor V.J. Gupta.

ProfessoR V.J. Gupta is now a famous person, not on the strength of his many spurious contributions to the literature of the palaeontology of the Himalayas, but because of the length of time during which the Panjab University of Chandigarh has failed to face the Gupta problem. Five years have passed since the case against Gupta appeared in print (see J.A. Talent Nature 338, 613-615; 1989). Now, after a two-year inquiry, Judge M.S. Gujral says that he has found "overwhelming" evidence that much of Gupta's published research is indeed fraudulent. And the punishment? The university senate has reprimanded Gupta, denied him further salary increments and decreed that he shall not in future hold an administrative post in the university. (By seniority, Gupta had been the next to take a turn as dean of the university.)

This is not simply a way of heaping one scandal on another; it is also a source of shame for the whole research community in India. It is particularly shocking that a person found to have put false research data into circulation should be allowed to continue teaching students, research students included. The university senate cannot avail itself of the excuse that Gupta would have been able to fight a more severe penalty through the tortuous Indian courts. Had it been externally constrained, it would not gratuitously hàve decreed that four of Gupta's co-authors should be stripped of whatever credit they may have earned in that unfortunate position.

It will be interesting and important to see what happens next. The best outcome would be that Gupta should simply resign, but that is simply an expression of the hope that the problem will go away. The university senate could also follow last month's timorous decision by calling for such a course of action. That, at least, would prevent Gupta from claiming that the mild penalties now decreed must be a sign that he has been innocent all along. But even that seems unlikely. Only five of the 55 members of the senate voted for a motion for his dismissal when the question came up last month. Indeed, it seems improbable that there will be a solution within Chandigarh.

That is why external influences should be mustered. In these unprecedented circumstances, it is not unreasonable that academic institutions elsewhere, even outside India, should make their opinions known to the university whenever they have dealings with it. Cutting off funds from the centre, on the other hand, would harm students at an institution that serves an valuable purpose regionally and (in agriculture) nationally. Meanwhile, Nature will keep in touch with Gupta's co-authors, much persecuted in the past five years, and will protest in public if they are further humiliated. At some stage, it must be hoped, the university at Chandigarh will begin to worry about its reputation. 